\title{
Recapitalization of Banks: Analysis of the Ghana Banking Industry
}

\author{
Bright Obuobi ${ }^{*}$, Emmanuel Nketiah ${ }^{1}$, Faustina Awuah ${ }^{2}$, Adelaide Gyanwah Amadi ${ }^{1}$ \\ ${ }^{1}$ School of Business, Nanjing University of Information Science \& Technology, Nanjing, China \\ ${ }^{2}$ University of Education, Winneba, Ghana \\ Email: ^obuobibright@gmail.com, ^nketia888@hotmail.com, awuahfaustina77@gmail.com, adelaidegyanwah@gmail.com
}

How to cite this paper: Obuobi, B., Nketiah, E., Awuah, F. and Amadi, A.G. (2020) Recapitalization of Banks: Analysis of the Ghana Banking Industry. Open Journal of Business and Management, 8, 78-103. https://doi.org/10.4236/ojbm.2020.81006

Received: November 6, 2019

Accepted: December 9, 2019

Published: December 12, 2019

Copyright (c) 2020 by author(s) and Scientific Research Publishing Inc. This work is licensed under the Creative Commons Attribution International License (CC BY 4.0).

http://creativecommons.org/licenses/by/4.0/

(c) (i) Open Access

\begin{abstract}
Recapitalization of banks has been a topic of discussion between politicians, economists, bank regulators, academicians and the general public due to its role in the country's economic growth. This reform has been implemented in a number of countries to improve a strong banking system of which Ghana is not an exception. The main objective of the study is to ascertain the effects of recapitalization on the Ghanaian banking sector. In a decade (2007 to 2017) there have been 3 various recapitalizations (2007, 2012 and 2017) of the Ghana banking industry. The study is conducted to prove if the recapitalization of banks has been worth it using the 2012 exercise as the benchmark. Various literatures are reviewed, and scholars cited. The study adopts quantitative research technique based on ex-post factor design. It uses secondary data on the research variables (cost to income ratio, profit before tax, non-performing loans, return on assets, return on equity, Net interest margin, capital adequacy ratio, liquidity ratios, asset quality ratios) over the period 2007 to 2018 . Analytical techniques of both descriptive statistics and independent sample test were adopted for the study. The t-test for equality of means was used to ascertain evidence of statistically significant difference in banking sector performance indicators and the Levene's test for equality of variance was also adopted. The study concludes that banking recapitalization has the potential to promote the performance of banks in the industry. Hence it was recommended that the central bank (BoG) initiates sufficient regulatory measures to sustain the benefits of banking recapitalization to benefit depositors and the nation as a whole.
\end{abstract}

\section{Keywords}

Post Recapitalization, Pre-Recapitalization, Bank of Ghana 


\section{Introduction}

In the modern economic world, the banking system plays an important role. The financial sector is crucial to the economies of various countries, and banks remain a core of the sector, especially in developing economies where the capital market is not strong enough [1]. The Africa banking sector and the rest of the developing world have undergone a significant transformation in their operating environment over the years. Recapitalization of banks has been one of the various bank reforms in recent years in developing and developed economies. As a result, understanding the impact of recapitalizing financial institutions specifically banks is crucial for both developed and developing economies. This study seeks to address whether or not recapitalization of banks is beneficial to the banking sector using Ghana's banking industry as a case study.

Recapitalization of banks has been a topic of discussion between politicians, economists, bank regulators, academicians and the general public due to its role in the country's economic growth. It is an aspect of banking industry reform that is focused on the need for existing banks' reorientation and repositioning in order to achieve an effective and efficient result. It is a strategy used to tackle banks' insolvency and prevent future financial distress possibilities. Most banks and financial institutions in Ghana and other countries have suffered due to recapitalization exercises whilst others have benefitted. However, the general impact of this exercise on the overall banking industry of a country remains an empirical one.

Addressing this issue, Adegbaju and Olokoyo [2] wrote that, recapitalization entails increasing the debt stock of a company or issuing additional shares through existing shareholders or new shareholders or a combination. Sani and Alani [3] also advocated that the objectives of recapitalization are to enable the banks to increase their market power, induce restructuring and engender the alignment and realignment of banks to ensure a good, responsive, competitive and transparent banking system suited to the demand of the Nigerian economy and the challenges of globalization. Okpanachi [4] in reference to the Nigeria banking recapitalization posited that recapitalization is carried out in order to arrest systems decay, restoration of public confidence, building of strong, competent and competitive players in the global arena, ensuring longevity and many more which acts as a springboard to achieving improved performance. Bakare [5] supported this statement and argued that apart from its multiplier effect on the economy as a whole, adequate capital acts as a buffer and security for banks.

Spong [6] in his study postulates that commercial banks must have adequate capital to provide a cushion for absorbing possible loan losses, fund for its internal needs, and expansion drives and added security for depositors. According to Spong [6], this can only be done through recapitalization. This specifically explains why Kanu and Isu [7] argued that many banks go out of their way to increase their capital even without the prompting of the Central Bank of Nigeria and this is because they believe a profitable banking sector is better able to with- 
stand negative shocks and contribute to the stability of the financial system.

Financial sector reforms have been implemented in a number of countries to improve a strong banking system. They control a large part of the money supply in circulation and can influence the nature and character of any country's production. When advanced countries pursue the right balance of financial regulation, whether by increasing capital requirements or by imposing restrictions on certain activities, it is essential to understand the possible cost of these laws.

Comparatively with developing countries precisely Africa, despite the financial sector reforms since the 1990s with an aim of improving profitability, efficiency and productivity, commercial banks' performance have remained poor with substantial gaps in service delivery to private agents [8]. However, this doesn't mean there isn't room for improvement. In recent years some of the African local banks have been performing tremendously due to similar financial reforms.

This study seeks to establish the impact of various capitalization on the Ghana banking industry. Since the introduction of a universal banking license in 2003, the Ghana banking industry has been in growth though the negative aspects can never be overlooked. Based on a limited capacity for dealing, the banking sector then was smaller. In the last sixteen years, the banking industry has gone through three recapitalization programmes. It began in 2007 when banks were tasked to recapitalize to GH $\$ 60$ million, then in 2012 when banks were directed to recapitalize up to $\mathrm{GH} \$ 120$ million and in 2017 when it was increased to GH\$400 million. Many believe the exercise wasn’t done appropriately and some banks could have been saved without necessarily recapitalizing the sector. But according to the Bank of Ghana, such recovery initiatives are systematically designed to make the banks bigger, more stable, and more robust in order to support the Ghanaian economy. With the diverse point of views, it calls for an empirical study to analyze whether recapitalization is the solution to the banking sector crises in Ghana.

\subsection{History and State of Banking in Ghana}

Banking in Ghana can be traced back to the early 1950s, when the Bank of England set up the Bank of Ghana in 1953. The Bank was subsequently divided into two: The Bank of Ghana, which acts as an issue bank, to be converted into a complete central bank; and the Ghana Commercial Bank, to become the largest commercial bank with a monopoly on public corporate accounts. On March 6, 1957, the Gold Coast attained independence from Great Britain and became known as Ghana. As expected, the Bank of Ghana took over the management of the currency and issued its first National Currency in July 1958; the Cedi to replace the old West African currency notes. The Ghana Commercial Bank assumed the role and functions of Government bankers and began to take over the finances of most Government departments and public corporations.

The Bank of Ghana (BoG) has been the central bank which oversees all operating banks in Ghana. The arrival of the new government led to the creation of 
more banks. Banks incorporated by legislation between the periods 1957 to 1965 include: The National Investment Bank as an Investment Banking Institution; the Agricultural Development Bank for the development of Agriculture; the Merchant Bank for merchant banking; and the Social Security Bank to encourage savings. All these institutions were established as state-owned banks in conformity with the economic policy of the time. In the early 1960s, Ghana suffered a serious economic crisis due to its socialist policies, including strict exchange control, trade deficits and import/export issues. This crisis continued until 1983, when there was a shift from economic socialism to a market economy.

However, the crisis in the sector and its timing can be related to the sharp decline in economic performance in the late 1970s. During the early years of independence, the history of the financial sector's growth was closely linked to comprehensive government policy after 1983. The government intervened in every sector of the economy in an attempt to rapid industrialization. Financial policies were established as part of an overall strategy for industrialization to replace imports. By the 1970s, issues like interest rate controls and credit ceilings ensured that cheap credit was available to government-imposed priority sectors such as manufacturing. Heavy taxation of the banking sector had become a major source of revenue for the government. High reserve requirements were placed on the banks. These and among other restrictive policies created major distortions in the financial sector.

In 1987, the Government of Ghana, in partnership with the World Bank, took steps to improve the banking and financial sector with a Financial Sector Adjustment Program. An economic recovery program was launched in 1983, seeking to restructure the economy and reverse economic decline trends. This made it quite clear to the government that a restructuring of the then troubled financial sector had to be pursued if economic reforms were to lead to a sustained recovery of growth in the economy. Starting in 1983, the Economic Recovery Program (ERP) aimed to stabilize the economy and then promote growth. The economic reforms included measures to promote fiscal discipline, trade and exchange system reforms, and other wide-ranging measures to initiate price liberalization and many economic activities deregulation. After the crisis, the Banking Law was enacted in 1989, enabling appropriate local bodies to file license applications for operating as banking institutions. Subsequently, a number of corporate entities were licensed to operate as banks, including Meridien (BIAO) Trust Bank, CAL Merchant Bank, Allied and Metropolitan and ECOBANK.

Nevertheless, in 1992, the government started privatizing some of the state-owned banks, and the financial sector's liberalization led to the entry of a number of foreign banks into the banking industry as well as an increase in the number of domestic banks. The liberalization of the financial sector under the Financial Sector Adjustment Programme (FINSAP) and Financial Sector Strategic Plan (FINSSIP) also brought about improved savings, enhanced deposit mobilization, financial deepening, and competition in the banking industry. However, lending rates were high with wider spread between deposit and lend- 
ing rates. In 2004, the new banking Act was enacted. The introduction of the new Banking Act also led to the elimination of secondary reserves and adjustments in the minimum capital. The minimum capital was initially increased to GHS 60 million in 2007 and then in 2012 it was increased to GHS 120 million. The new Act also saw the introduction of the Universal banking license, which allows banking to provide various forms of banking services. Mergers and acquisitions of some banks also emerged largely on account of the surge in the minimum capital requirement with recent examples including Access Bank and Intercontinental Bank, Ecobank and TTB Bank, and HFC Bank and Republic Bank of Trinidad and Tobago.

Recently, Ghana undertook a serious clean-up exercise in the banking sector in order to protect depositors' money and avoid bankruptcy. This emerged from mismanagement and unavailability of the stated capitals of some banks. The mismanagement of funds and illegal use of the stated capitals of UT Bank and Capital bank prompted the BoG to further look into all banks to ensure a robust financial sector. This led to the shutting down of the aforementioned banks and granted a takeover by the GCB Bank. As a result, the Bank of Ghana (BoG) in accordance with Section 28 (1) of the Banks and Specialized Deposit-Taking Institutions Act, 2016 (Act 930), revised upward the minimum paid-up capital for existing banks and new entrants from GH\$120 million to a new level of $\mathrm{GH} \$ 400$ million (233.33\% increase) from the effective date of 11th September 2017 and banks ought to comply by end of December 2018. The aim of the recapitalization according to the BoG is to "further develop, strengthen and modernize the financial sector to support the Government's economic vision and transformational agenda". With this directive, banks were given these three options to raise additional capital.

1) Fresh capital injection.

2) Capitalization of income surplus.

3) A combination of fresh capital injection and capitalization of income surplus.

As at $31^{\text {st }}$ December 2018 which happened to be the deadline for banks, there were 23 universal banks that have all met the new minimum paid-up capital of GHC400 million.

According to BoG, out of the 23 banks, sixteen banks met the new minimum paid-up capital requirement of GH $\$ 400$ million mainly through capitalization of income surplus and fresh capital injection. The 16 banks are Zenith Bank, Ecobank, GCB Bank, Stanbic Bank, Standard Chartered Bank and Barclays Bank. The others are Access Bank, Consolidated Bank, Republic Bank, Fidelity Bank, UBA, Societe Generale, GT Bank, FBN Bank, Cal Bank, and Bank of Africa.

Due to the inability of some banks to meet the requirements, the Bank of Ghana approved three applications for mergers. First Atlantic Bank, Merchant Bank Limited and Energy Commercial Bank merged, Omni Bank and Bank Sahel Sahara merged, and First National Bank and GHL Bank merged as well. The three resulting banks out of these mergers met the new minimum capital re- 
quirement. Their process was successful because private pension funds in Ghana injected fresh equity capital into five indigenous banks through a special purpose holding company named Ghana Amalgamated Trust Limited (GAT). In addition, the state-owned banks ADB and NIB also benefitted from the GAT scheme. The other beneficiary banks (the merged Omni/Bank Sahel Sahara, Universal Merchant Bank, and Prudential Bank) were selected by GAT on the basis of their solvent status and good corporate governance [9].

In total, the Bank of Ghana has revoked licenses of nine (9) banks in efforts to clean up the banking sector and restore stability and resilience of the financial system. These banks are Heritage Bank, Limited, Premium Bank Limited, uniBank, Sovereign bank, BEIGE bank, Royal bank, Construction bank, UT bank and Capital bank (Table 1).

Table 1. Banks in Ghana after the clean-up exercise.

\begin{tabular}{|c|c|c|c|}
\hline & Banks & $\begin{array}{l}\text { Previous } \\
\text { names }\end{array}$ & $\begin{array}{l}\text { Majority } \\
\text { ownership }\end{array}$ \\
\hline 1 & Access Bank (Ghana) Plc & & Foreign \\
\hline 2 & Agricultural Development Bank Limited & & Local \\
\hline 3 & Bank of Africa Ghana Limited & & Foreign \\
\hline 4 & Barclays Bank of Ghana Limited & & Foreign \\
\hline 5 & CAL Bank Limited & & Local \\
\hline \multirow[b]{2}{*}{6} & & $\begin{array}{c}\text { Construction Bank } \\
\text { Beige Bank }\end{array}$ & \multirow[b]{2}{*}{ Local } \\
\hline & Consolidated Bank Ghana Limited & $\begin{array}{c}\text { Royal Bank } \\
\text { UniBank } \\
\text { Sovereign Bank }\end{array}$ & \\
\hline 7 & Ecobank Ghana Limited & & Foreign \\
\hline 8 & FBNBank (Ghana) Limited & & Foreign \\
\hline 9 & Fidelity Bank Ghana Limited & & Local \\
\hline 10 & First Atlantic Bank Limited & & Foreign \\
\hline 11 & First National Bank (Ghana) Limited & & Foreign \\
\hline 12 & GCB Bank Limited & & Local \\
\hline 13 & GHL Bank Limited & & Foreign \\
\hline 14 & Guaranty Trust Bank (Ghana) Limited & & Foreign \\
\hline 15 & National Investment Bank Limited & & Local \\
\hline 16 & OmniBSIC Bank Ghana Limited & $\begin{array}{c}\text { Omni Bank Ghana Limited } \\
\text { Sahel Sahara Bank } \\
\text { Ghana Limited (BSIC) }\end{array}$ & Local \\
\hline 17 & Prudential Bank Limited & & Local \\
\hline 18 & Republic Bank (Ghana) Limited & & Foreign \\
\hline 19 & Societe General (Ghana) Limited & & Foreign \\
\hline 20 & Stanbic Bank Ghana Limited & & Foreign \\
\hline 21 & $\begin{array}{c}\text { Standard Chartered } \\
\text { Bank (Ghana) Limited }\end{array}$ & & Foreign \\
\hline 22 & United Bank for Africa (Ghana) Limited & & Foreign \\
\hline 23 & Universal Merchant Bank Limited & & Local \\
\hline 24 & Zenith Bank (Ghana) Limited & & Foreign \\
\hline
\end{tabular}

Note: First National Bank and GHL Bank are in the process of merging. 
In the course of the clean-up exercise over $\mathrm{GH} \$ 12$ billion was spent to protect depositors from losing their funds [9] (Table 2).

\subsection{Statement of the Problem}

The shutting down and revocation of banks' license became a shock to the general public when the news out broke. To the ordinary Ghanaian, almost every bank seemed to be doing very well on the outside. This boosted their confidence to save and invest with them until the BoG brought the eye-opener news which placed most Ghanaians in shock, panic and fear. Concerning issues surrounding banking in Ghana, Narh [10] wrote that, the scenario of banking in Ghana has been characterized by low capitalization which consequently affected their investments. He added that, Banks were not in a good standing to finance big projects because they lack the financial muscle to be players in industries that require higher funds to be able to invest in them such as the up-coming oil industry at that time. While re-capitalization of Ghana banks may seem to address this concern, the effect of the exercise on banks performance remains an empirical one. In a decade (2007 to 2017) there have been 3 various recapitalizations of the Ghana banking industry. Is it worth it?

\subsection{Objective of the Study}

The main objective of the study is to ascertain the effect of the recapitalization on the Ghana banking sector. Specifically, the objectives of the study include:

Evaluate the effects of recapitalization on the capital adequacy of commercial banks in Ghana

Table 2. Performance of the Ghana banking industry.

\begin{tabular}{ccccccccccccc}
\hline Year/variable & CIR & $\begin{array}{c}\text { Profit } \\
\text { before } \\
\text { Tax (\%) }\end{array}$ & $\begin{array}{c}\text { (NIM) } \\
(\%)\end{array}$ & $\begin{array}{c}\text { Asset } \\
\text { Quality } \\
=\end{array}$ & $\begin{array}{c}\text { Asset } \\
\text { Quality } \\
=\end{array}$ & $\begin{array}{c}\text { Liquidity } \\
=\end{array}$ & $\begin{array}{c}\text { Liquidity } \\
=\end{array}$ & $\begin{array}{c}\text { Non-Performing } \\
\text { Loan (NPL) }\end{array}$ & $\begin{array}{c}\text { CAR } \\
\text { ROA }\end{array}$ & $\begin{array}{c}\text { ROE } \\
\text { (Before tax) }\end{array}$ \\
$(\mathrm{after}$ tax)
\end{tabular}

Source: (PwC Ghana Bank survey 2010 to 2019 and BoG 2019). 
Evaluate the effects of recapitalization on the efficiency of commercial banks in Ghana.

Evaluate the effects of recapitalization on the asset quality of commercial banks in Ghana.

Evaluate the effects of recapitalization on profitability of commercial banks in Ghana.

Evaluate the effects of recapitalization on liquidity of commercial banks in Nigeria

\section{Literature Review}

The scope of this research and analysis were such that a large body of published work could be referenced. However, because the scope of this study was to investigate the impact of the recapitalization of the Ghanaian banking industry, the literature review forming the substance of this chapter was deliberately restricted to cover papers relevant to the different facets of this study. This chapter reviews existing empirical research regarding the profitability, performance and state of banks with respect to regulatory capital increase. The aim of this literature review is to provide a comprehensive overview of important findings from other studies and to provide an explanation of possible inconsistencies and deficiencies in current literature.

Recapitalization is the process of restructuring the debt and equity balance of a company, often to make the capital structure of a company more stable. It is basically the strategy used by a company to boost its financial stability or to overhaul its financial structure. The method involves effectively swapping one form of financing for another, such as withdrawing preferred shares from the capital structure of the company and replacing them with bonds. If banks are stuck in a position where their debts are comparatively higher than their assets, the recapitalization plan comes into effect. Bank liquidity is a liability as it is the money that customers deposit, which has to be paid sooner or later. As a result, their balance-sheet weakens, and banks find it difficult to raise capital from the open market. The organization must adjust its debt-to-equity ratio to achieve this. This is done by adding more debt or more equity to its capital. There are many reasons why a company may consider to undergo recapitalization including:

$>$ When share prices fall.

$>$ To protect itself against a hostile takeover attempt.

To reduce financial obligations and minimize taxes.

To provide venture capitalists with an exit strategy.

$>$ Bankruptcy.

If the debt of a company decreases in proportion to its equity, it has a lower leverage. Its earnings per share (EPS) should also decrease following the change. But its shares would be increasingly less risky as the company has fewer debt obligations, requiring interest payments and return on maturity of the principal. 
The company can return more of its profits and cash to shareholders without debt requirements.

\section{Empirical Studies on Recapitalization of Banks}

A banking reform's main objective is to improve bank performance and boost economic growth. Banking reform studies suggest contrasting views on the effect of a banking reform on banking industry efficiency and the contribution to economic growth. In some cases, it did not help economic growth even though it improved upon banking performance [11] in Thai banking industry; [12] in Turkish banking sector. Others experience both increase in performance and central bank's objective of improving economic growth [13]. Globally, commercial and universal banks have not taken re-capitalization exercise from central banks kindly [14] [15].

An earlier study by Berger [16] on U.S. banks using data from 1983-1989, found a positive relationship between the capital ratio and the return on equity. Berger's argument supporting this relationship was based on the expected bankruptcy costs, which may be relatively high for a bank maintaining capital ratios below its equilibrium values. A subsequent increase in capital ratio should result in an increase in the return on equity by lowering insurance expenses on uninsured debt. An after study by Kosmidou et al. [17] on the profitability of UK owned commercial banks during the period 1995-2002 using fixed effect panel regression, showed a consistent result with Berger [16] that capitalization has a positive and dominant influence on profitability.

Adegbaju and Olokoyo [2] studied the effect of bank recapitalization on bank performance in Nigeria using the statistical test of difference of means. Data on key profit performance indicators like yield on earning assets (YEA), return on equity (ROE) and return on assets (ROA) covering pre-consolidation period of 1998-2000 and post consolidation period of 2002-2004 were analyzed. The result shows that the means of YEA, ROE and ROA significantly differ between the periods. The study was based on the 2001 bank recapitalization exercise.

Owolabi and Ogunlalu [18] also examined the effect of banking consolidation on the performance of selected banks in Nigeria using 5-year pre and post-consolidation data on net profit margin (NPM), return on assets (ROA) and return on capital employed (ROCE). Statistical test of equality of means were used to analyze data to ascertain whether or not there exist evidence of significant difference between the means of these variables as a result of the exercise. Four banks were selected between the periods of 2001-2010 for the study. The found evidence was a significant difference between mean of ROCE in the pre and post-consolidation periods but not for NPM and ROA.

Boahene et al. [19] studied on profitability of Ghanaian banks and found support for previous empirical works that, capital influence bank profitability positively and significantly. Boahene et al. [19] used a five-year (2005-2009) panel data from six selected commercial banks, which was analyzed using the fixed-effect panel model. 
Sufian \& Chong [20] in examining the determinants of the profitability of banks in the Philippines during the period 1990 to 2005, found that capitalization has a positive impact on bank profitability (ROE). They argued further that banks in developing countries require a strong capital structure, because it offers them strength to withstand financial crises and offers depositors a better safety net in times of bankruptcy and distress macroeconomic conditions. A latter study on inter-country basis by Naceur \& Omran [21] showed that bank capitalization and credit risk, have a positive and significant impact on banks' net interest-margin (NIM), cost efficiency, and profitability. Their work which capture a longer period of 1988-2005 on MENA (Middle East and North African) countries, using the linear dynamic panel data model analysis, is consistent with the findings of Sufian \& Chong [20] on a single country within almost the same period. Naceur \& Omran [21] also found that regulatory reform variables seem to have an impact on bank performance.

Oleka and Mgbodile [22] studied 17 of the 25 banks that emerged from the 89 banks in operation in 2004 before the reform covering a ten year-period (2002 to 2012) to see the significance of the reform. The study found that, there was significant difference in the performance of banks before and after the reforms as evidenced by improved yields in the ratios used as performance measures. The ratios used in this work as performance indicators showed higher yields in post-recapitalization compared to lower yields prior to the change. They concluded that by increasing operational efficiency and increasing their earnings potential, it has changed the market structures of banks.

Sani, and Alani, [3] as cited in Obadan [23] held the opinion that the N25 billion would not guarantee banks soundness unless fundamental cases of distress in the banks are tackled. They itemized some factors which included adverse internal and external stocks, unstable economic policies, adverse conditions and unguarded liberations of entry into banking industry, reckless use of depositor's fund and inadequate supervision and enforcement of regulations may constitute some draw backs to the policy.

Trujillo-Ponce [24] and Martins et al., [25] examined empirically the main determinants of banks profitability for Spain in the period 1999-2009. The conclusion of study posits that, a higher level of capitalization of analyzed banks had a positive impact on the return on average assets (ROAA) but impacts negatively on the return on Average Equity (ROAE). This is inconsistent with other results from studies in some European economies on the impact of capital and ROE. The study also shows that the rate of growth of deposits, size and income diversification does not have an impact on banks profitability. In terms of external factors, market concentration, economic cycle, the inflation rate and the interest rate have influenced banks profitability. Trujillo-Ponce's [24] study affirms the assertion by Asedionlen [26] that, a re-capitalization may raise liquidity in a short term but will not guarantee a conducive macroeconomic environment required to ensure high asset quality and good profitability.

The study conducted by Raji et al., [27] using the random effect instead of 
fixed effect result due to Hausman test suggestion revealed that, recapitalization does not improve the performance of banks measured by ROA. This was however in line with the findings of [28] [29] which indicates that recapitalization have fail or has negative effect on bank's profitability performance.

Finally, a study conducted by Athanasoglou et al. [30] adopted the Generalized Method of Moments (GMM) using the paradigm of Arellano and Bond (1991) of one lagged GMM to find the impact of bank recapitalization exercise in Ghana on the profitability performance of banks. The study also investigated whether economic factors have effect on the relationship between regulatory capital increase and the profitability of banks. The study found that, the Return on Equity (ROE) using the test of equality of means was insignificant. The test on equality of means for Return on Assets (ROA) using the t-test of equality of means were insignificant. The result means there is no statistical difference between the mean of pre-recapitalization ROE and post-recapitalization of the banks. The same applied to pre and post recapitalization ROA. But the test was significant for the pre-recapitalization After-Tax Profit and post-recapitalization After-Tax Profit. This means that, the recapitalization exercise has helped increase the After-Tax Profit significantly. From the empirical result, the recapitalization exercise had a negative, significant impact on banks' profitability. $\mathrm{He}$ concluded that, the regulatory capital increment for banks in Ghana, has not helped the profitability of the Ghanaian banking industry as far as returns to shareholders is concerned. It also added that while recapitalization raised the capital base of the banks, it is not all the time that it transforms into good financial intermediation.

\section{Methodology}

\section{Description of Variables}

Credit agencies, researchers, and bank regulators have been evaluating banks' performance on the basis of a formal approach called CAMELS bank assessment system.

The CAMELS rating is a supervisory rating system that originated from the United States to classify a bank's overall condition. The ratings are assigned based on ratio analysis of the financial statement combined with on-site examinations made by a designated supervisory regulator. The components of a bank's condition that are assessed includes six performance measures: capital adequacy, asset quality, efficiency, profitability/earning, liquidity and sensitivity to market risk. This study settled for the first five which includes Capital adequacy, Asset quality, Earnings/profitability and Liquidity but also added other indicators beneficial to banks performance assessment (Table 3).

\section{Data and Methodology}

\subsection{Data Collection}

The study adopts quantitative research technique based on ex-post facto design. 
Table 3. Definition and explanation of variables.

\begin{tabular}{|c|c|c|}
\hline Variable & Description & Calculation \\
\hline $\begin{array}{l}\text { Cost to income ratio } \\
\text { (CIR) }\end{array}$ & $\begin{array}{l}\text { Also called the cost/income ratio or } \mathrm{C} / \mathrm{I} \text { ratio is the measure of the } \\
\text { costs of running a company in relation to its operating income. } \\
\text { The ratio gives investors a clear view of how efficiently the company is } \\
\text { being run. The lower the } \mathrm{C} / \mathrm{I} \text { ratio is, the more profitable it should be. }\end{array}$ & $=\frac{\text { operating expenses }}{\text { operating income }}$ \\
\hline $\begin{array}{l}\text { Profit before tax } \\
\qquad(\mathrm{PBT})\end{array}$ & $\begin{array}{l}\text { PBT is a measure that looks at a company's profits before the } \\
\text { company has to pay corporate income tax. It deducts all expenses } \\
\text { from revenue including interest expenses and operating } \\
\text { expenses except for income tax. }\end{array}$ & $\begin{array}{l}\text { = income }- \text { operating expenses } \\
\text { (including interest but not tax) }\end{array}$ \\
\hline $\begin{array}{l}\text { Net interest margin } \\
\text { (NIM) }\end{array}$ & $\begin{array}{l}\text { NIM is the ratio of net interest income to invested assets. } \\
\text { A positive net interest margin means the investment strategy pays } \\
\text { more interest than it costs. Conversely, if net interest margin } \\
\text { is negative, it means the investment strategy costs more than it makes. }\end{array}$ & $=\frac{\text { Interest Received }- \text { Interest Paid }}{\text { Average Invested Assets }}$ \\
\hline Asset Quality & $\begin{array}{l}\text { A measure of the likelihood of default of a loan, combined with a } \\
\text { measure of its marketability. It is a measure of the price at which a } \\
\text { bank or other financial institution can sell a loan or lease to a } \\
\text { third party, as determined by the borrower. We consider } \\
\text { Asset quality ratio. i.e. impairment charge to loan and advances } \\
\text { Impairment allowance to loan and advances }\end{array}$ & $\begin{array}{l}=\frac{\text { Impairment charge }}{\text { Loan and advances }} \\
=\frac{\text { Impairment allowance }}{\text { Loans and advances }}\end{array}$ \\
\hline Liquidity & $\begin{array}{l}\text { Liquidity is the ability to convert assets into cash quickly and } \\
\text { cheaply. Liquidity ratios are an important class of financial } \\
\text { metrics used to determine a debtor's ability to pay off current } \\
\text { debt obligations without raising external capital. We consider } \\
\text { Liquid funds to total deposits and Liquid funds to total assets. }\end{array}$ & $\begin{array}{l}=\frac{\text { Liquid funds }}{\text { Total deposits }} \\
=\frac{\text { Liquid funds }}{\text { Total assets }}\end{array}$ \\
\hline $\begin{array}{l}\text { Return on assets } \\
\quad(\mathrm{ROA})\end{array}$ & $\begin{array}{l}\text { ROA is an indicator of how profitable a company is relative to its } \\
\text { total assets. ROA gives a manager, investor, or analyst an idea as to } \\
\text { how efficient a company's management is at using its assets to } \\
\text { generate earnings. Return on assets is usually expressed as a percentage. }\end{array}$ & $=\frac{\text { Net income }}{\text { Total assets }}$ \\
\hline $\begin{array}{l}\text { Return on equity } \\
\quad \text { (ROE) }\end{array}$ & $\begin{array}{l}\text { ROE is considered a measure of how effectively management is } \\
\text { using a company's assets to create profits. A good or bad ROE } \\
\text { will depend on what's normal for the industry or company peers. } \\
\text { Relatively high or low ROE ratios will vary significantly } \\
\text { from one industry group or sector to another. }\end{array}$ & $=\frac{\text { Net income }}{\text { Averaged shareholders equity }}$ \\
\hline $\begin{array}{l}\text { Non-Performing Loans } \\
\text { (NPL) }\end{array}$ & $\begin{array}{l}\text { The sum of borrowed money upon which the debtor has not } \\
\text { made the scheduled payments for a specified period. It is considered } \\
\text { in default or close to default. Once a loan is non-performing, } \\
\text { the odds the debtor will repay it in full are substantially lower. }\end{array}$ & $=\frac{\text { Total NPL }}{\text { Total outstanding loans }}$ \\
\hline $\begin{array}{l}\text { Capital adequacy ratio } \\
\text { (CAR) }\end{array}$ & $\begin{array}{l}\text { The measurement of a bank's available capital expressed as a } \\
\text { percentage of a bank's risk-weighted credit exposures. It is used } \\
\text { to protect depositors and promote the stability and efficiency of } \\
\text { financial systems. Two types of capital are measured: tier-1 capital, } \\
\text { which can absorb losses without a bank being required to cease } \\
\text { trading, and tier-2 capital, which can absorb losses in the event } \\
\text { of a winding-up and so provides a lesser degree of } \\
\text { protection to depositors. }\end{array}$ & $=\frac{\text { Tier } 1 \text { capital }+ \text { Tier } 2 \text { capital }}{\text { Risk weighted assets }}$ \\
\hline
\end{tabular}

It uses secondary data on the research variables (cost to income ratio, profit before tax, non-performing loans, return on assets, return on equity, Net interest margin, capital adequacy ratio, liquidity ratio, asset quality) over the period 2007 
to 2018 were sourced from the annual Ghana banks survey report of $\mathrm{PwC}$ and the Central Bank of Ghana (BoG) reports. Analytical techniques of both descriptive statistics and independent sample test were adopted for the study. The t-test was used to ascertain evidence of statistically significant difference in banking sector performance indicators (cost to income ratio, profit before tax, non-performing loans, return on assets, return on equity, Net interest margin, capital adequacy ratio, liquidity ratio, asset quality) between pre and post-recapitalization periods. Though Ghana has had 3 various capitalization within the time period under study $(2007,2012$ and 2017) but for the purpose of this study, the 2012 exercise was used as the basis of assessment.

Time period (Pre-capitalization $)=2007-2012=6$.

Time period $($ Post capitalization $)=2013-2018=6$.

\subsubsection{Hypothesis}

The null hypothesis $\left(H_{0}\right)$ and alternative hypothesis $\left(H_{1}\right)$ of the Independent Samples $t$ Test can be expressed in two different but equivalent ways:

$$
\begin{aligned}
& H_{0}: \mu_{1}=\mu_{2} \text { ("the two-population means are equal"). } \\
& H_{1}: \mu_{1} \neq \mu_{2} \quad \text { ("the two-population means are not equal"). }
\end{aligned}
$$

\subsubsection{Levene's Test for Equality of Variances}

The independent Samples $t$ Test requires the assumption of homogeneity of variance that is both groups have the same variance. A test for the homogeneity of variance, called Levene's Test.

The hypotheses for Levene's test are:

$$
H_{0}: \sigma_{1^{2}}-\sigma_{2^{2}}=0 \text { ("the population variances of group } 1 \text { and } 2 \text { are equal"). }
$$

$H_{1}: \sigma_{1^{2}}-\sigma_{2^{2}} \neq 0$ ("the population variances of group 1 and 2 are not equal").

This implies that if we reject the null hypothesis of Levene's Test, it suggests that the variances of the two groups are not equal; i.e., that the homogeneity of variances assumption is violated.

\subsubsection{Test Statistic}

The test statistic for an Independent Samples $t$ Test is denoted t. There are actually two forms of the test statistic for this test, depending on whether or not equal variances are assumed.

\subsubsection{Equal Variances Assumed}

When the two independent samples are assumed to be drawn from populations with identical population variances (i.e., $\sigma_{1^{2}}=\sigma_{2^{2}}$ ), the test statistic $t$ is calculated as:

$$
t=\frac{\bar{x}_{1}-\bar{x}_{2}}{s_{p} \sqrt{\frac{1}{n_{1}}+\frac{1}{n_{2}}}}
$$

with

$$
S_{p}=\sqrt{\frac{\left(n_{1}+1\right) S_{1}^{2}+\left(n_{2}+1\right) S_{2}^{2}}{n_{1}+n_{2}-2}}
$$


where:

$$
\begin{aligned}
& \bar{x}_{1}=\text { Mean of first sample. } \\
& \bar{x}_{2}=\text { Mean of second sample. } \\
& n_{1}=\text { Sample size (that is number of observations) of first sample. } \\
& n_{2}=\text { Sample size (that is number of observations) of second sample. } \\
& s_{1}=\text { Standard deviation of first sample. } \\
& s_{2}=\text { Standard deviation of second sample. } \\
& s_{p}=\text { Pooled standard deviation. }
\end{aligned}
$$

\subsubsection{Equal Variances Not Assumed}

When the two independent samples are assumed to be drawn from populations with unequal variances (i.e., $\sigma_{1^{2}} \neq \sigma_{2^{2}}$ ), the test statistic $t$ is calculated as:

$$
t=\frac{\bar{x}_{1}-\bar{x}_{2}}{s_{p} \sqrt{\frac{1}{n_{1}}+\frac{1}{n_{2}}}}
$$

where:

$\bar{x}_{1}=$ Mean of first sample.

$\bar{x}_{2}=$ Mean of second sample.

$n_{1}$ = Sample size (that is number of observations) of first sample.

$n_{2}=$ Sample size (that is number of observations) of second sample.

$s_{1}=$ Standard deviation of first sample.

$s_{2}=$ Standard deviation of second sample.

The calculated $t$ value is then equated to the critical $t$ value from the $t$ distribution table with degrees of freedom

$$
d f=\frac{\left(\frac{S_{1}^{2}}{n_{1}}+\frac{S_{2}^{2}}{n_{2}}\right)}{\frac{1}{n_{1}-1}\left(\frac{S_{1}^{2}}{n_{1}}\right)^{2}+\frac{1}{n_{1}-2}\left(\frac{S_{2}^{2}}{n_{2}}\right)^{2}}
$$

\subsection{Results, Data Analysis and Discussion}

\subsubsection{Cost to Income Ratio (CIR)}

Table 4 shows the descriptive statistics for Cost to income ratio in the pre and post capitalization periods. The result shows a decrease in the performance of cost to income ratio from a mean of 0.5867 to 0.5200 per cent for the pre and post capitalization periods respectively. The observed reduction in cost to income ratio suggests an evidence of a better administration policy in the post capitalization period (Table 4). This implies an improvement in efficiency of the sector after the re-capitalization exercise.

Based on Levene's Test for Equality of Variances when the p-value is less than $5 \%$ implies that we reject Null hypothesis, suggesting that the variances of the two groups are not equal. Table 5 shows a value of 0.843 indicating that we accept Null hypothesis that is $P>0.05$, which suggests the variance of the two groups are equal. 
Table 4. Descriptive statistics.

\begin{tabular}{cccccccccc}
\hline & Period & N & Mini & Maxi & Mean & Std. error Mean & Std. Deviation & Variance \\
\hline \multirow{2}{*}{ CIR } & Pre & 6 & 0.52 & 0.60 & 0.5867 & 0.01333 & 0.03266 & 0.001 \\
& Post & 6 & 0.47 & 0.54 & 0.5200 & 0.01095 & 0.02683 & 0.001 \\
\hline
\end{tabular}

Table 5. Independent samples test.

\begin{tabular}{|c|c|c|c|c|c|c|c|c|c|c|}
\hline & & \multicolumn{2}{|c|}{$\begin{array}{c}\text { Levene's Test for } \\
\text { Equality of Variances }\end{array}$} & \multicolumn{7}{|c|}{ t-test for Equality of Means } \\
\hline & & \multirow[t]{2}{*}{$\mathrm{F}$} & \multirow{2}{*}{ Sig. } & \multirow[t]{2}{*}{$\mathrm{T}$} & \multirow{2}{*}{$\mathrm{df}$} & \multirow{2}{*}{$\begin{array}{c}\text { Sig. } \\
\text { (2-tailed) }\end{array}$} & \multirow{2}{*}{$\begin{array}{c}\text { Mean } \\
\text { Difference }\end{array}$} & \multirow{2}{*}{$\begin{array}{l}\text { Std. Error } \\
\text { Difference }\end{array}$} & \multicolumn{2}{|c|}{$\begin{array}{l}\text { Confidence Interval o } \\
\text { the Difference } 95 \%\end{array}$} \\
\hline & & & & & & & & & Lower & Upper \\
\hline \multirow{2}{*}{ CIR } & $\begin{array}{l}\text { Equal variances } \\
\text { assumed }\end{array}$ & 0.041 & 0.843 & 3.863 & 10 & 0.003 & 0.06667 & 0.01726 & 0.02822 & 0.10512 \\
\hline & $\begin{array}{c}\text { Equal variances } \\
\text { not assumed }\end{array}$ & & & 3.863 & 9.637 & 0.003 & 0.06667 & 0.01726 & 0.02802 & 0.10531 \\
\hline
\end{tabular}

Following an independent sample test of equality of means (Table 5) conducted to determine evidence of significant difference the pre- and post-capitalization means, the result shows that at 5 per cent level of significance, there is a significant difference between pre- and post-capitalization means of Cost of Income Ratio (CIR) $(p(0.003<0.05))$. The null hypothesis of no statistical significance is thereby rejected (Table 5$)$.

\subsubsection{Profit before Tax (PBT)}

The descriptive statistic for profit before tax in the pre and post-capitalization periods presented in Table 6 shows an increase in the mean values of return on assets from 28.533 to 37.083 per cent for the pre and post capitalization periods respectively. This suggests an increase in the profitability of the banking sector due to implementation of the capitalization exercise.

Based on Levene's Test for Equality of Variances when the p-value is less than $5 \%$ implies that we reject Null hypothesis, suggesting that the variances of the two groups are not equal. Table 7 shows a value of 0.737 indicating that we accept Null hypothesis that is $P>0.05$, which suggest the variance of the two groups are equal.

Following an independent sample test of equality of means (Table 7) conducted to determine evidence of significant difference the pre and post-capitalization means, the result shows that at 5 per cent level of significance, there is a significant difference between pre and post-capitalization means of Profit before tax (PBT) $(p(0.003<0.05))$. The null hypothesis of no statistical significance is thereby rejected (Table 7). This is in consistent with Naceur and Omran [21] study which suggests capitalization has a positive significant impact on cost efficiency.

\subsubsection{Net Interest Margin (NIM)}

The descriptive statistic for Net interest margin in the pre and post-capitalization 
Table 6. Descriptive statistics.

\begin{tabular}{ccccccccc}
\hline & Period & N & Mini & Maxi & Mean & Std. error Mean & Std. Deviation & Variance \\
\hline \multirow{2}{*}{ PBT } & Pre & 6 & 19.7 & 37.3 & 28.533 & 2.3800 & 5.8298 & 33.987 \\
& Post & 6 & 29.5 & 45.2 & 37.083 & 2.5565 & 6.2621 & 39.214 \\
\hline
\end{tabular}

Table 7. Independent samples test.

\begin{tabular}{|c|c|c|c|c|c|c|c|c|c|c|}
\hline & & \multicolumn{2}{|c|}{$\begin{array}{l}\text { Levene's Test for } \\
\text { Equality of Variances }\end{array}$} & \multicolumn{7}{|c|}{ t-test for Equality of Means } \\
\hline & & \multirow{2}{*}{$\mathrm{F}$} & \multirow{2}{*}{ Sig. } & \multirow[t]{2}{*}{$\mathrm{T}$} & \multirow{2}{*}{ df } & \multirow{2}{*}{$\begin{array}{c}\text { Sig. } \\
\text { (2-tailed) }\end{array}$} & \multirow{2}{*}{$\begin{array}{c}\text { Mean } \\
\text { Difference }\end{array}$} & \multirow{2}{*}{$\begin{array}{l}\text { Std. Error } \\
\text { Difference }\end{array}$} & \multicolumn{2}{|c|}{$\begin{array}{l}\text { Confidence Interval } \\
\text { of the Difference } 95 \%\end{array}$} \\
\hline & & & & & & & & & Lower & Upper \\
\hline $\begin{array}{l}\text { Profit } \\
\text { before }\end{array}$ & $\begin{array}{l}\text { Equal variances } \\
\text { assumed }\end{array}$ & 0.120 & 0.737 & -2.448 & 10 & 0.034 & -8.5500 & 3.4929 & -16.333 & -0.7674 \\
\hline $\operatorname{Tax}(\%)$ & $\begin{array}{l}\text { Equal variances } \\
\text { not assumed }\end{array}$ & & & -2.448 & 9.949 & 0.034 & -8.5500 & 3.4929 & -16.338 & -0.7620 \\
\hline
\end{tabular}

periods presented in Table 8 shows an increase in the mean values of Net interest margin from 7.883 to 9.300 per cent for the pre and post capitalization periods respectively. This suggests that the investment strategies implemented after the capitalization paid more interest than its cost compared to the pre-capitalization period. An indication of a positive impact of the capitalization exercise.

Based on Levene's Test for Equality of Variances, Table 9 shows a value of 0.197 indicating that we accept Null hypothesis that is $P>0.05$, which suggests the variance of the two groups are equal.

Following an independent sample test of equality of means (Table 9) conducted to determine evidence of significant difference the pre and post-capitalization means, the result shows that at 5 per cent level of significance, there is a significant difference between pre- and post-capitalization means of Net interest margin (NIM) $(p(0.025<0.05))$. The null hypothesis of no statistical significance is thereby rejected (Table 9). This is in consistency with Naceur and Omran [21] study which suggests capitalization has a positive significant impact on NIM.

\subsubsection{Asset Quality 1}

The descriptive statistic for Asset quality 1 (impairment charge to loan and advances) Impairment allowance to loan and advances in the pre and post-capitalization periods presented in Table 10 shows an increase in the mean values of impairment charge to loan and advances from 2.867 to 3.150 for the pre and post capitalization periods respectively. This suggests an increase in the asset quality measured by impairment charge to loan and advances of the banking sector due to implementation of the capitalization exercise.

Based on Levene's Test for Equality of Variances Table 11 shows a value of 0.719 indicating that we accept Null hypothesis that is $P>0.05$, which suggest 
Table 8. Descriptive statistics.

\begin{tabular}{cccccccccc}
\hline & Period & N & Mini & Maxi & Mean & Std. error Mean & Std. Deviation & Variance \\
\hline \multirow{2}{*}{ NIM } & Pre & 6 & 6.6 & 9.4 & 7.883 & 0.4629 & 1.1339 & 1.286 \\
& Post & 6 & 8.0 & 9.8 & 9.300 & 0.2757 & 0.6753 & 0.456 \\
\hline
\end{tabular}

Table 9. Independent samples test.

\begin{tabular}{|c|c|c|c|c|c|c|c|c|c|c|}
\hline & & \multicolumn{2}{|c|}{$\begin{array}{c}\text { Levene's Test for } \\
\text { Equality of Variances }\end{array}$} & \multicolumn{7}{|c|}{ t-test for Equality of Means } \\
\hline & & \multirow[t]{2}{*}{$\mathrm{F}$} & \multirow{2}{*}{ Sig. } & \multirow[t]{2}{*}{$\mathrm{T}$} & \multirow{2}{*}{ Df } & \multirow{2}{*}{$\begin{array}{c}\text { Sig. } \\
\text { (2-tailed) }\end{array}$} & \multirow{2}{*}{$\begin{array}{c}\text { Mean } \\
\text { Difference }\end{array}$} & \multirow{2}{*}{$\begin{array}{l}\text { Std. Error } \\
\text { Difference }\end{array}$} & \multicolumn{2}{|c|}{$\begin{array}{l}\text { Confidence Interval } \\
\text { of the Difference } 95 \%\end{array}$} \\
\hline & & & & & & & & & Lower & Upper \\
\hline \multirow{2}{*}{$\begin{array}{c}(\mathrm{NIM}) \\
(\%)\end{array}$} & $\begin{array}{l}\text { Equal variances } \\
\text { assumed }\end{array}$ & 1.915 & 0.197 & -2.629 & 10 & 0.025 & -1.417 & 0.539 & -2.617 & -0.216 \\
\hline & $\begin{array}{l}\text { Equal variances } \\
\text { not assumed }\end{array}$ & & & -2.629 & 8.150 & 0.030 & -1.417 & 0.539 & -2.655 & -0.178 \\
\hline
\end{tabular}

Table 10. Descriptive statistics.

\begin{tabular}{cccccccccc}
\hline & Period & N & Mini & Maxi & Mean & Std. error Mean & Std. Deviation & Variance \\
\hline $\begin{array}{c}\text { Asset } \\
\text { Quality } 1\end{array}$ & Pre & 6 & 1.5 & 4.7 & 2.867 & 0.5194 & 1.2723 & 1.619 \\
\hline
\end{tabular}

Table 11. Independent samples test.

\begin{tabular}{|c|c|c|c|c|c|c|c|c|c|c|}
\hline & & \multicolumn{2}{|c|}{$\begin{array}{l}\text { Levene's Test for } \\
\text { Equality of Variances }\end{array}$} & \multicolumn{7}{|c|}{$\mathrm{t}$-test for Equality of Means } \\
\hline & & \multirow[t]{2}{*}{$\mathrm{F}$} & \multirow[t]{2}{*}{ Sig. } & \multirow[t]{2}{*}{$\mathrm{t}$} & \multirow[t]{2}{*}{ Df } & \multirow{2}{*}{$\begin{array}{c}\text { Sig. } \\
\text { (2-tailed) }\end{array}$} & \multirow{2}{*}{$\begin{array}{c}\text { Mean } \\
\text { Difference }\end{array}$} & \multirow{2}{*}{$\begin{array}{l}\text { Std. Error } \\
\text { Difference }\end{array}$} & \multicolumn{2}{|c|}{$\begin{array}{l}\text { Confidence Interval } \\
\text { of the Difference } 95 \%\end{array}$} \\
\hline & & & & & & & & & Lower & Upper \\
\hline $\begin{array}{l}\text { Asset Quality } 1 \\
\text { (impairment }\end{array}$ & $\begin{array}{l}\text { Equal variances } \\
\text { assumed }\end{array}$ & 0.137 & 0.719 & -0.398 & 10 & 0.699 & -0.2833 & 0.7115 & -1.8687 & 1.3021 \\
\hline $\begin{array}{l}\text { charge to loan } \\
\text { and advances) }\end{array}$ & $\begin{array}{l}\text { Equal variances } \\
\text { not assumed }\end{array}$ & & & -0.398 & 9.957 & 0.699 & -0.2833 & 0.7115 & -1.8697 & 1.3030 \\
\hline
\end{tabular}

the variance of the two groups are equal.

Following an independent sample test of equality of means (Table 11) conducted to determine evidence of significant difference the pre and post-capitalization means, the result shows that at 5 per cent level of insignificance, there is an insignificant difference between pre and post-capitalization means of impairment charge to loan and advances $(p(0.699>0.05))$. The null hypothesis of no statistical significance is thereby accepted (Table 11).

\subsubsection{Asset Quality 2}

The descriptive statistic for Asset quality 1 (Impairment allowance to loan and advances) in the pre and post-capitalization periods presented in Table 12 
Table 12. Descriptive statistics.

\begin{tabular}{cccccccccc}
\hline & Period & N & Mini & Maxi & Mean & Std. error Mean & Std. Deviation & Variance \\
\hline $\begin{array}{c}\text { Asset } \\
\text { Quality 2 }\end{array}$ & Pre & 6 & 4.6 & 9.4 & 7.183 & 0.8280 & 2.0282 & 4.114 \\
\hline
\end{tabular}

shows an increase in the mean values of Impairment allowance to loan and advances from 7.182 to 8.033 for the pre and post capitalization periods respectively. This is an additional confirmation to the increase in the asset quality in this case measured by impairment allowance to loan and advances of the banking sector due to implementation of the capitalization exercise.

Based on Levene's Test for Equality, Table 13 shows a value of 0.931 indicating that we accept Null hypothesis that is $P>0.05$, which suggests the variance of the two groups are equal.

Following an independent sample test of equality of means (Table 13) conducted to determine evidence of significant difference the pre and post-capitalization means, the result shows that at 5 per cent level of insignificance, there is an insignificant difference between pre and post-capitalization means of impairment allowance to loan and advances $(p(0.499>0.05))$. The null hypothesis of no statistical significance is thereby accepted (Table 13).

\subsubsection{Liquidity 1}

The descriptive statistic for Liquidity 1 (Liquid funds to total deposits) in the pre and post-capitalization periods presented in Table 14 shows an increase in the mean values of Liquid funds to total deposits from 0.64 to 0.758 for the pre and post capitalization periods respectively. This suggests an increase in Liquidity measured in liquid funds to total deposits of the banking sector indicating a positive ability of the sector to pay its debt obligations and margin of safety due to implementation of the capitalization exercise. This is consistent with Asedionlen [26] study which states that recapitalization may raise liquidity in short term.

Based on Levene's Test for Equality of Variances Table 15 shows a value of 0.552 indicating that we accept Null hypothesis that is $P>0.05$, which suggest the variance of the two groups are equal.

Following an independent sample test of equality of means (Table 15) conducted to determine evidence of significant difference the pre and post-capitalization means, the result shows that at 5 per cent level of significance, there is a significant difference between pre- and post-capitalization means of Liquid funds to total deposits $(p(0.05=0.05))$. The null hypothesis of no statistical significance is thereby rejected (Table 15 ).

\subsubsection{Liquidity 2}

The descriptive statistic for Liquidity 2 (Liquid funds to total assets) in the pre and post-capitalization periods presented in Table 16 shows an increase in the mean values of Liquid funds to total assets from 0.493 to 0.543 for the pre and post capitalization periods respectively. This further suggests an increase in the 
Table 13. Independent samples test.

\begin{tabular}{|c|c|c|c|c|c|c|c|c|c|c|}
\hline & & \multicolumn{2}{|c|}{$\begin{array}{c}\text { Levene's Test for } \\
\text { Equality of Variances }\end{array}$} & \multicolumn{7}{|c|}{ t-test for Equality of Means } \\
\hline & & \multirow[t]{2}{*}{$\mathrm{F}$} & \multirow{2}{*}{ Sig. } & \multirow[t]{2}{*}{$\mathrm{t}$} & \multirow{2}{*}{ Df } & \multirow{2}{*}{$\begin{array}{c}\text { Sig. } \\
\text { (2-tailed) }\end{array}$} & \multirow{2}{*}{$\begin{array}{c}\text { Mean } \\
\text { Difference }\end{array}$} & \multirow{2}{*}{$\begin{array}{l}\text { Std. Error } \\
\text { Difference }\end{array}$} & \multicolumn{2}{|c|}{$\begin{array}{l}\text { Confidence Interval } \\
\text { of the Difference } 95 \%\end{array}$} \\
\hline & & & & & & & & & Lower & Upper \\
\hline $\begin{array}{l}\text { Asset Quality } 2 \\
\text { (impairment }\end{array}$ & $\begin{array}{l}\text { Equal variances } \\
\text { assumed }\end{array}$ & 0.008 & 0.931 & -0.702 & 10 & 0.499 & -0.850 & 1.2105 & -3.547 & 1.847 \\
\hline $\begin{array}{l}\text { allowance to loan } \\
\text { and advances) }\end{array}$ & $\begin{array}{c}\text { Equal variances } \\
\text { not assumed }\end{array}$ & & & -0.702 & 9.959 & 0.499 & -0.850 & 1.211 & -3.549 & 1.849 \\
\hline
\end{tabular}

Table 14. Descriptive statistics.

\begin{tabular}{ccccccccc}
\hline & Period & N & Mini & Maxi & Mean & Std. error Mean & Std. Deviation & Variance \\
\hline $\begin{array}{c}\text { Liquidity 1 } \\
\begin{array}{c}\text { (Liquid funds to } \\
\text { total deposits) }\end{array}\end{array}$ & Pre & 6 & 0.53 & 0.73 & 0.6400 & 0.03376 & 0.08270 \\
\hline
\end{tabular}

Table 15. Independent samples test.

\begin{tabular}{|c|c|c|c|c|c|c|c|c|c|c|}
\hline & & $\begin{array}{r}\text { Lever } \\
\text { Equalit }\end{array}$ & st for & \multicolumn{7}{|c|}{ t-test for Equality of Means } \\
\hline & & \multirow[t]{2}{*}{$\mathrm{F}$} & \multirow[t]{2}{*}{ Sig. } & \multirow[t]{2}{*}{$\mathrm{t}$} & \multirow[t]{2}{*}{$\mathrm{df}$} & \multirow{2}{*}{$\begin{array}{c}\text { Sig. } \\
\text { (2-tailed) }\end{array}$} & \multirow{2}{*}{$\begin{array}{c}\text { Mean } \\
\text { Difference }\end{array}$} & \multirow{2}{*}{$\begin{array}{l}\text { Std. Error } \\
\text { Difference }\end{array}$} & \multicolumn{2}{|c|}{$\begin{array}{l}\text { Confidence Interval } \\
\text { of the Difference } 95 \%\end{array}$} \\
\hline & & & & & & & & & Lower & Upper \\
\hline \multirow{2}{*}{$\begin{array}{l}\text { Liquidity } 1 \\
\text { (Liquid funds to } \\
\text { total deposits) }\end{array}$} & $\begin{array}{c}\text { Equal variances } \\
\text { assumed }\end{array}$ & .379 & .552 & -2.230 & 10 & 0.050 & -0.118 & 0.053 & -0.237 & -0.000 \\
\hline & $\begin{array}{c}\text { Equal variances } \\
\text { not assumed }\end{array}$ & & & -2.230 & 9.650 & 0.051 & -0.118 & 0.053 & -0.237 & 0.001 \\
\hline
\end{tabular}

Table 16. Descriptive statistics.

\begin{tabular}{ccccccccc}
\hline & Period & N & Mini & Maxi & Mean & Std. error Mean & Std. Deviation & Variance \\
\hline $\begin{array}{c}\text { Liquidity 2 } \\
\text { (Liquid funds } \\
\text { to total assets) }\end{array}$ & Pre & 6 & 0.41 & 0.54 & 0.493 & 0.002 & 0.019 & 0.047 \\
\hline
\end{tabular}

liquidity measured in liquid funds to total assets of the banking sector indicating a positive ability of the sector to pay its debt obligations and margin of safety due to implementation of the capitalization exercise. This is consistent with Asedionlen [26] study which states that recapitalization may raise liquidity in short term.

Based on Levene's Test for Equality of Variances Table 17 shows a value of 0.507 indicating that we accept Null hypothesis that is $P>0.05$, which suggest the variance of the two groups are equal.

Following an independent sample test of equality of means (Table 17) conducted to determine evidence of significant difference the pre and post-capitalization 
Table 17. Independent samples test.

\begin{tabular}{|c|c|c|c|c|c|c|c|c|c|c|}
\hline & & \multicolumn{2}{|c|}{$\begin{array}{c}\text { Levene's Test for } \\
\text { Equality of Variances }\end{array}$} & \multicolumn{7}{|c|}{ t-test for Equality of Means } \\
\hline & & \multirow[t]{2}{*}{$\mathrm{F}$} & \multirow[t]{2}{*}{ Sig. } & \multirow[t]{2}{*}{$\mathrm{t}$} & \multirow{2}{*}{$\mathrm{df}$} & \multirow{2}{*}{$\begin{array}{c}\text { Sig. } \\
\text { (2-tailed) }\end{array}$} & \multirow{2}{*}{$\begin{array}{c}\text { Mean } \\
\text { Difference }\end{array}$} & \multirow{2}{*}{$\begin{array}{l}\text { Std. Error } \\
\text { Difference }\end{array}$} & \multicolumn{2}{|c|}{$\begin{array}{l}\text { Confidence Interval } \\
\text { of the Difference } 95 \%\end{array}$} \\
\hline & & & & & & & & & Lower & Upper \\
\hline \multirow{2}{*}{$\begin{array}{c}\text { Liquidity } 2 \\
\text { (Liquid funds } \\
\text { to total assets) }\end{array}$} & $\begin{array}{c}\text { Equal variances } \\
\text { assumed }\end{array}$ & 0.474 & 0.507 & -1.623 & 10 & 0.136 & -0.050 & 0.031 & -0.119 & 0.019 \\
\hline & $\begin{array}{c}\text { Equal variances } \\
\text { not assumed }\end{array}$ & & & -1.623 & 9.547 & 0.137 & -0.050 & 0.031 & -0.119 & 0.019 \\
\hline
\end{tabular}

means, the result shows that at 5 per cent level of insignificance, there is an insignificant difference between pre- and post-capitalization means of Liquid funds to total assets $(p(0.136>0.05))$. The null hypothesis of no statistical significance is thereby accepted (Table 17).

\subsubsection{Return on Assets (ROA)}

The descriptive statistic for return on assets in the pre- and post-capitalization periods presented in Table 18 shows an increase in the mean values of return on assets from 3.7067 to 4.7017 per cent for the pre- and post-capitalization periods respectively. This suggests an increase in the profitability of earning assets of the banking sector due to implementation of the recapitalization exercise. This implies an increase in efficiency after the recapitalization exercise. This is in consistency with Trujillo-Ponce \& Martins [24] which states capitalization has a positive impact on ROAA. It is also in consistency with Kosmidu et al. [17] which states capitalization has a positive impact on profitability. It is however inconsistent with Raji et al's [27] study which states recapitalization does not improve performance.

Based on Levene's Test for Equality of Variances Table 19 shows a value of 0.057 indicating that we accept Null hypothesis that is $P>0.05$, which suggests the variance of the two groups are equal.

However, given that the significance value (0.150) of the test is greater than 0.05 . The result of this study therefore suggests that the average difference of 0.995 percent in the performance of return on asset for the pre and post-consolidation periods is not significant (Table 18 and Table 19). The study therefore does not reject the null hypothesis that there is no significant difference in return on asset between the pre and post capitalization periods. This is consistent with the studies of Owolabi and Ogunlalu [18], Athanasoglou et al. [30] and Trujillo-Ponce \& Martins [24] which states capitalization has a positive insignificant impact on profitability measured by ROA. This is inconsistent with Boahene et al. [19] which states recapitalization has a positive significant impact on profitability

\subsubsection{Return on Equity (ROE)}

The descriptive statistic for return on equity in the pre- and post-capitalization 
Table 18. Descriptive statistics.

\begin{tabular}{cccccccccc}
\hline & Period & N & Mini & Maxi & Mean & Std. error Mean & Std. Deviation & Variance \\
\hline $\begin{array}{c}\text { Return on } \\
\text { assets (ROA) }\end{array}$ & Pre & 6 & 2.83 & 4.85 & 3.7067 & 0.27908 & 0.68360 & 0.467 \\
\hline
\end{tabular}

Table 19. Independent samples test.

\begin{tabular}{|c|c|c|c|c|c|c|c|c|c|c|}
\hline & & \multicolumn{2}{|c|}{$\begin{array}{c}\text { Levene's Test for } \\
\text { Equality of Variances }\end{array}$} & \multicolumn{7}{|c|}{ t-test for Equality of Means } \\
\hline & & \multirow[t]{2}{*}{$\mathrm{F}$} & \multirow[t]{2}{*}{ Sig. } & \multirow[t]{2}{*}{$\mathrm{T}$} & \multirow[t]{2}{*}{ Df } & \multirow{2}{*}{$\begin{array}{c}\text { Sig. } \\
\text { (2-tailed) }\end{array}$} & \multirow{2}{*}{$\begin{array}{c}\text { Mean } \\
\text { Difference }\end{array}$} & \multirow{2}{*}{$\begin{array}{l}\text { Std. Error } \\
\text { Difference }\end{array}$} & \multicolumn{2}{|c|}{$\begin{array}{l}\text { Confidence Interval } \\
\text { of the Difference } 95 \%\end{array}$} \\
\hline & & & & & & & & & Lower & Upper \\
\hline \multirow{2}{*}{$\begin{array}{c}\text { ROA } \\
\text { (Before tax) }\end{array}$} & $\begin{array}{l}\text { Equal variances } \\
\text { assumed }\end{array}$ & 4.609 & 0.057 & -1.561 & 10 & 0.150 & -0.995 & 0.638 & -2.415 & 0.425 \\
\hline & $\begin{array}{c}\text { Equal variances } \\
\text { not assumed }\end{array}$ & & & -1.561 & 7.245 & 0.161 & -0.995 & 0.638 & -2.492 & 0.502 \\
\hline
\end{tabular}

periods presented in Table 18 shows an increase in the mean values of return on assets from 22.162 to 23.480 per cent for the pre- and post-capitalization periods respectively. This suggests an increase in the profitability to shareholders of the banking sector due to implementation of the recapitalization exercise. This implies that returns to shareholders increased after the recapitalization exercise. It is in consistency with Berger [16], Trujillo-Ponce \& Martins [24] and Sufian \& Chong's [20] study which states ROE has a positive impact on ROE, ROAE and ROE respectively. It is also in consistency with Kosmidu et al. [17] which states capitalization has a positive impact on profitability. It is however inconsistent with Raji et al.'s [27] study which states recapitalization does not improve performance (Table 20).

Based on Levene's Test for Equality of Variances, Table 21 shows a value of 0.052 indicating that we accept Null hypothesis that is $P>0.05$, which suggest the variance of the two groups are equal.

Following an independent sample test of equality of means (Table 21) conducted to determine evidence of significant difference the pre and post-capitalization means, the result shows that at 5 per cent level of insignificance, there is an insignificant difference between pre- and post-capitalization means of returns on equity $(p(0.681>0.05))$. The null hypothesis of no statistical significance is thereby accepted (Table 21). This is consistent with the study by Athanasoglou et al. [30] which states capitalization has a positive insignificant impact on profitability measured by ROE. It is also inconsistent with Boahene et al. [19] which states recapitalization has a positive significant impact on profitability.

\subsubsection{Non-Performing Loans (NPL)}

Table 22 shows the descriptive statistics for non-performing loans in the pre-and post-capitalization periods. The result shows an increase in the 
Table 20. Descriptive statistics.

\begin{tabular}{cccccccccc}
\hline & Period & N & Mini & Maxi & Mean & Std. error Mean & Std. Deviation & Variance \\
\hline $\begin{array}{c}\text { Return on } \\
\text { equity (ROE) }\end{array}$ & Pre & 6 & 17.50 & 25.83 & 22.162 & 1.406 & 3.445 & 11.866 \\
\hline
\end{tabular}

Table 21. Independent samples test.

\begin{tabular}{|c|c|c|c|c|c|c|c|c|c|c|}
\hline & & \multicolumn{2}{|c|}{$\begin{array}{l}\text { Levene's Test for } \\
\text { Equality of Variances }\end{array}$} & \multicolumn{7}{|c|}{ t-test for Equality of Means } \\
\hline & & \multirow[t]{2}{*}{$\mathrm{F}$} & \multirow[t]{2}{*}{ Sig. } & \multirow[t]{2}{*}{$\mathrm{T}$} & \multirow[t]{2}{*}{ Df } & \multirow{2}{*}{$\begin{array}{c}\text { Sig. } \\
\text { (2-tailed) }\end{array}$} & \multirow{2}{*}{$\begin{array}{c}\text { Mean } \\
\text { Difference }\end{array}$} & \multirow{2}{*}{$\begin{array}{l}\text { Std. Error } \\
\text { Difference }\end{array}$} & \multicolumn{2}{|c|}{$\begin{array}{l}\text { Confidence Interval } \\
\text { of the Difference 95\% }\end{array}$} \\
\hline & & & & & & & & & Lower & Upper \\
\hline \multirow{2}{*}{$\begin{array}{c}\text { ROE } \\
\text { (after tax) }\end{array}$} & $\begin{array}{l}\text { Equal variances } \\
\text { assumed }\end{array}$ & 4.858 & 0.052 & -0.423 & 10 & 0.681 & -1.318 & 3.113 & -8.255 & 5.618 \\
\hline & $\begin{array}{c}\text { Equal variances } \\
\text { not assumed }\end{array}$ & & & -0.423 & 7.405 & 0.684 & -1.318 & 3.113 & -8.599 & 5.962 \\
\hline
\end{tabular}

Table 22. Descriptive statistics.

\begin{tabular}{ccccccccc}
\hline & Period & N & Mini & Maxi & Mean & Std. error Mean & Std. Deviation & Variance \\
\hline \multirow{2}{*}{ NPL } & Pre & 6 & 6.91 & 17.60 & 12.625 & 1.800 & 4.409 & 19.441 \\
& Post & 6 & 10.98 & 21.59 & 15.787 & 1.637 & 4.010 & 16.081 \\
\hline
\end{tabular}

performance of nonperforming loans from a mean of 12.6250 to 15.7867 per cent for the pre- and post-capitalization periods. The observed increase in non-performing loans suggests an evidence that the administrative policy in the post capitalization period (Table 22) was unfavorable as far as Non-performing loans is concerned. This implies an underperformance of Non-performing loans of the sector after the capitalization exercise.

Based on Levene's Test for Equality of Variances Table 23 shows a value of 0.789 indicating that we accept Null hypothesis that is $P>0.05$, which suggests the variance of the two groups are equal.

Following an independent sample test of equality of means (Table 23) conducted to determine evidence of significant difference the pre- and post-capitalization means, the result shows that at 5 per cent level of significance, there is no significant difference between pre- and post-capitalization means of non-performing loans $(p(0.223>0.05))$. The null hypothesis of no statistical significance is thereby accepted (Table 23).

\subsubsection{Capital Adequacy Ratio (CAR)}

Table 24 shows the descriptive statistic for capital adequacy ratio in the pre- and post-capitalization periods. The means for capital adequacy ratio between the respective periods shows an increase from 17.1950 to 18.3417 (Table 24). This is a further evidence that protection of depositors and promoting the stability and efficiency of financial systems of the sector increased by $1.1 \%$ due to the recapitalization exercise.

Based on Levene's Test for Equality of Variances, Table 25 shows a value of 
Table 23. Independent samples test.

\begin{tabular}{|c|c|c|c|c|c|c|c|c|c|c|}
\hline & & \multicolumn{2}{|c|}{$\begin{array}{l}\text { Levene's Test for } \\
\text { Equality of Variances }\end{array}$} & \multicolumn{7}{|c|}{ t-test for Equality of Means } \\
\hline & & \multirow{2}{*}{$\mathrm{F}$} & \multirow{2}{*}{ Sig. } & \multirow{2}{*}{$\mathrm{t}$} & \multirow{2}{*}{ df } & \multirow{2}{*}{$\begin{array}{c}\text { Sig. } \\
\text { (2-tailed) }\end{array}$} & \multirow{2}{*}{$\begin{array}{c}\text { Mean } \\
\text { Difference }\end{array}$} & \multirow{2}{*}{$\begin{array}{l}\text { Std. Error } \\
\text { Difference }\end{array}$} & \multicolumn{2}{|c|}{$\begin{array}{l}\text { Confidence Interval } \\
\text { of the Difference 95\% }\end{array}$} \\
\hline & & & & & & & & & Lower & Upper \\
\hline \multirow{2}{*}{$\begin{array}{l}\text { Non-Performing } \\
\text { Loan (NPL) }\end{array}$} & $\begin{array}{l}\text { Equal variances } \\
\text { assumed }\end{array}$ & 0.075 & 0.789 & -1.299 & 10 & 0.223 & -3.162 & 2.433 & -8.583 & 2.260 \\
\hline & $\begin{array}{c}\text { Equal variances } \\
\text { not assumed }\end{array}$ & & & -1.299 & 9.911 & 0.223 & -3.162 & 2.433 & -8.590 & 2.266 \\
\hline
\end{tabular}

Table 24. Descriptive statistics.

\begin{tabular}{ccccccccc}
\hline & Period & N & Mini & Maxi & Mean & Std. error Mean & Std. Deviation & Variance \\
\hline \multirow{2}{*}{ CAR } & Pre & 6 & 13.84 & 19.84 & 17.195 & 0.981 & 2.403 & 5.775 \\
& Post & 6 & 17.81 & 19.27 & 18.342 & 0.221 & .540 & 0.292 \\
\hline
\end{tabular}

Table 25. Independent samples test.

\begin{tabular}{|c|c|c|c|c|c|c|c|c|c|c|}
\hline & & \multicolumn{2}{|c|}{$\begin{array}{l}\text { Levene's Test for } \\
\text { Equality of Variances }\end{array}$} & \multicolumn{7}{|c|}{ t-test for Equality of Means } \\
\hline & & \multirow[t]{2}{*}{$\mathrm{F}$} & \multirow[t]{2}{*}{ Sig. } & \multirow[t]{2}{*}{$\mathrm{t}$} & \multirow[t]{2}{*}{$\mathrm{df}$} & \multirow{2}{*}{$\begin{array}{c}\text { Sig. } \\
\text { (2-tailed) }\end{array}$} & \multirow{2}{*}{$\begin{array}{c}\text { Mean } \\
\text { Difference }\end{array}$} & \multirow{2}{*}{$\begin{array}{l}\text { Std. Error } \\
\text { Difference }\end{array}$} & \multicolumn{2}{|c|}{$\begin{array}{l}\text { Confidence Interval } \\
\text { of the Difference } 95 \%\end{array}$} \\
\hline & & & & & & & & & Lower & Upper \\
\hline \multirow{2}{*}{ CAR } & $\begin{array}{l}\text { Equal variances } \\
\text { assumed }\end{array}$ & 9.907 & 0.010 & -1.140 & 10 & 0.281 & -1.147 & 1.005 & -3.387 & 1.094 \\
\hline & $\begin{array}{l}\text { Equal variances } \\
\text { not assumed }\end{array}$ & & & -1.140 & 5.504 & 0.301 & -1.147 & 1.005 & -3.662 & 1.369 \\
\hline
\end{tabular}

0.010 indicating that we reject Null hypothesis that is $P<0.05$, which suggests the variance of the two groups are not equal.

From the independent sample test presented in Table 25, the difference in the means between the two periods was shown to be insignificant at 5 per cent level of significance. Hence, the null hypothesis of no statistical significance is thereby accepted.

\section{Conclusions and Policy Implication}

\subsection{Conclusions}

The Levene's Test for Equality of Variances to determine the significance or otherwise of variance among the independent samples in the two groups shows that, the respective variances for the pre and post capitalization of CIR, NIM, PBT, Asset quality, Liquidity, ROE, ROA and NPL are insignificant at 5\% level indicating the variance between the two groups are equal as far as these variables are concerned. However, CAR shows a significant variance of 0.010 at $5 \%$ level indicating the variances between the two groups are not equal. 
The independent $t$-test conducted to ascertain significance or otherwise of the mean difference among the independent samples under investigation produced mixed results as follows:

There is significant improvement in cost to income ratio, net interest margin and profit before tax in the Ghanaian banking sector following the implementation of the capitalization exercise in 2012 as shown in the respective tables.

It is evident that, there is significant improvement in liquidity as measured in liquid funds to deposits but insignificant improvement in liquid funds to total assets as shown in Table 15 and Table 17 respectively.

There is also no evidence of significant difference for the means of return on assets, return on equity, capital adequacy ratio and banking sector's assets quality between the periods. There was also an insignificant but increase in non-performing loans in the industry.

\subsection{Policy Implication}

According to the study by Athanasoglou et al. [30], recapitalization has a negative significant impact and has not helped profitability of banks measured by ROE in Ghana. However, our study had a different point of view because bank performance can be measured in various ways which include efficiency. Some variables measuring profitability may be insignificant but record a positive result (ROE and ROA). In addition, Cost to income ratio, net interest margin and profit before tax which are good measurement tools for banks profitability and efficiency proved a positive significant result. Based on the above findings, the study concludes banking recapitalization has the potential to promote the performance of the banking sector, particularly with respect to delivery of its core mandate of driving economic growth and protecting depositors' money through banking operations. Based on this result, it is believed that the recapitalization exercise conducted by the Bank of Ghana in 2017 will have a greater positive impact on the sector in the long run.

It is recommended that sufficient regulatory measures be put in place to maintain the benefits of banking recapitalization as well as contain the incidence of sharp practices in the sector. It is also important to ensure that the exercise does not produce banks that may become overly influential making it uneasy to be effectively supervised as this may threaten the sector's stability. Lastly, there should be adequate customer and depositors' education on banking and its associated risks to enlighten them on what is associated with their investments and savings in order to influence their decisions positively.

In the future, a study will be conducted to make a short-term-aftermath comparison among the three-respective recapitalization exercise using monthly data to determine the level of effectiveness and efficiency of recapitalization on the industry.

\section{Conflicts of Interest}

The authors declare no conflicts of interest regarding the publication of this paper. 


\section{References}

[1] Matthew, N.G. and Laryea, A.E. (2012) A Financial Performance Comparison of Foreign vs. Local Banks in Ghana. International Journal of Business and Social Science, 3, 82-87.

[2] Adegbaju, A.A. and Olokoyo, F.O. (2008) Recapitalization and Banks' Performance: A Case Study of Nigerian Banks. African Economic and Business Review, 6, 1-12.

[3] Sani, J. and Alani, G.O. (2013) A Comparative Analysis of Pre- and Post-Recapitalization Financial Performance of Banks in Nigeria. International Journal of Capacity Building in Education and Management, 2, 79-90.

[4] Joshua, O. (2011) Comparative Analysis of the Impact of Mergers and Acquisitions on Financial Efficiency of Banks in Nigeria. Journal of Accounting and Taxation, 3, 1-7.

[5] Bakare, A.S. (2011) The Trend and Growth Implications of Bank Recapitalization in Nigeria. African Journal of Business Management, 5, 5938-5945.

[6] Spong, K. (1990) Banking Regulations: Its Purposes, Implementation and Effects. Federal Reserve Bank of Kansas City, USA Extracted on 29th March 2012.

[7] Kanu, C. and Isu, G.I. (2016) Security Challenge, Bank Fraud and Commercial Bank Performance in Nigeria: An Evaluation. Journal of Business and Management, 5, 1-21. https://doi.org/10.12735/jbm.v5n2p01

[8] Munyambonera Ezra Francis (2010) Determinants of Commercial Banks' Profitability in Sub-Saharan Africa.

[9] Bank of Ghana (2018) Annual Report. The Editorial Committee Bank of Ghana. https://www.bog.gov.gh/publications/annual-report

[10] Narh, M. (2013) BOG Sets Minimum Capital Requirement for New Banks. Citifmonline, Accra.

[11] Leightner, J.E. and Lovell, C.A.K. (1998) The Impact of Financial Liberalization on the Performance of Thai Banks. Journal of Economics and Business, 50, 115-131. https://doi.org/10.1016/S0148-6195(97)00073-8

[12] Denizer, C., Dinc, M. and Tarimcilar, M. (2007) Financial Liberalization and Banking Efficiency: Evidence from Turkey. Journal of Productivity Analysis, 27, 177-195. https://doi.org/10.1007/s11123-007-0035-9

[13] Shanmugam, K.R. and Das, A. (2004) Efficiency of Indian Commercial Banks in India during the Reform Period. Applied Financial Economics, 14, 681-686. https://doi.org/10.1080/0960310042000233458

[14] Kehinde, A.A., Joseph, N.T. and Folasade, B.A. (2018) Regulations of Other Financial Institutions in a Banking System Growth. Journal of Economic \& Management Perspectives, 12, 71-81.

[15] Benjamin-Addy, E. (2013) The Banking Sector in Ghana: Issues in Relation to Current Reforms. Business Economics-Economics Policy. Academic Paper, 133 p.

[16] Berger, A.N. (1995) The Relationship between Capital and Earnings in Banking. Journal of Money Credit and Banking, 27, 432-456. https://doi.org/10.2307/2077877

[17] Kosmidou, K., Tanna, S. and Pasiouras, F. (2008) Determinants of Profitability of Domestic UK Commercial Banks: Panel Evidence from the Period 1995-2002. Economics, Finance and Accounting Applied Research Working Paper Series No. RP08-4, Coventry University, Coventry, 1-28.

[18] Owolabi, S.A. and Ogunlalu, A.E. (2013) Banking Industry Consolidation and Financial Performance of Selected Quoted Banks in Nigeria. Journal of Applied Finance and Banking, 3, 219-238. 
[19] Boahene, S.H., Dasa, J. and Agyei, S.K. (2012) Credit Risk and Profitability of Selected Banks in Ghana. Research Journal of Finance and Accounting, 3, 6-14.

[20] Sufian, F. and Chong, R.R. (2008) Determinants of Bank Profitability in a Developing Economy: Empirical Evidence from Philippines. Asian Academy of Management Journal of Accounting and Finance, 4, 91-112.

[21] Naceur, S.B. and Omran, M. (2011) The Effects of Bank Regulations, Competition, and Financial Reforms on Banks' Performance. Emerging Markets Review, 12, 1-20. http://www.ghanaweb.com/GhanaHomePage/economy/artikel.php?ID=282601 https://doi.org/10.1016/j.ememar.2010.08.002

[22] Oleka and Mgbodile (2014) Recapitalization Reform and Bank's Performance: Empirical Evidence from Nigeria. Research Journal of Finance and Accounting, 5, 96-101.

[23] Obadan, M.I. (2004) Globalization and Economic Management in Africa, Globalization and Africa's Economic Development. Nigerian Economic Society, Ibadan, 3-34.

[24] Trujillo-Ponce, A. (2013) What Determines the Profitability of Banks? Evidence from Spain. Accounting \& Finance, 53, 561-586.

https://doi.org/10.1111/j.1467-629X.2011.00466.x

[25] Martins, A.M., Serra, A.P. and Stevenson, S. (2019) Determinants of Real Estate Bank Profitability. Research in International Business and Finance, 49, 282-300. https://doi.org/10.1016/j.ribaf.2019.04.004

[26] Asediolen, A. (2004) For the Economic and Financial Interest of Nigeria. Nigerworld: $1 \& 2$.

[27] Sadiq, R., Fatima, B., Bukonla, O. and Mobolaji, A. (2017) Effect of Recapitalization on Banks' Financial Performance in Nigeria. International Journal of Contemporary Research and Review, 9.

[28] Badreldin, A. and Kalhoefer, C. (2009) The Effect of Mergers and Acquisitions on Bank Performance in Egypt. Journal of Management Technology, 8, 1-15.

[29] Straub, T. (2007) Reasons for Frequent Failure in Mergers and Acquisitions. Springer, Berlin. https://doi.org/10.1007/978-3-8350-9637-0

[30] Athanasoglou, P.P., Brissimis, S.N. and Delis, M.D. (2005) Bank-Specific, Industry-Specific and Macroeconomic Determinants of Bank Profitability. Bank of Greece, Working Paper No. 25. 